\title{
Penerapan Model Scramble untuk Meningkatkan Motivasi Belajar Pada Mata Pelajaran Pendidikan Kewarganegaraan (PKn)
}

\author{
Prodensia Tuku $^{\text {a, } 1^{*} \text {, Bhakti Prima Findiga Hermuttaqien }}{ }^{\text {b, } 2}$, Iskandar Ladamay ${ }^{\text {c, } 3}$ \\ ${ }^{\text {a,c }}$ Universitas Kanjuruhan Malang, Indonesia \\ ${ }^{\mathrm{b}}$ Universitas Negeri Makassar, Indonesia \\ 1 tukuprodensia18@gmail.com*; bhakti@unm.ac.id ;iskandar@unikama.ac.id \\ *korespondensi penulis
}

\begin{tabular}{l} 
Informasi artikel \\
\hline Kata kunci: \\
Model Scramble \\
Motivasi Belajar \\
Mata Pelajaran \\
PKn
\end{tabular}

Keywords:

Scramble model

learning

motivation

PKn subjects

Copyright $\odot 2019 \overline{(\text { Prodensia Tuku, Bhakti P. F. Hermuttaqien. Iskandar Ladamay). All Right Reserved }}$

How to Cite: Tuku, P., Hermuttaqien, B., \& Ladamay, I. (2019). Penerapan Model Scramble untuk Meningkatkan Motivasi Belajar pada Mata Pelajaran Pendidikan Pancasila dan Kewarganegaraan. Jurnal Inspirasi Pendidikan, 9(1), 45-51.

This work is licensed under a Creative Commons Attribution-ShareAlike 4.0 International License. Allows readers to read, download, copy, distribute, print, search, or link to the full texts of its articles and allow readers to use them for any other lawful purpose. The journal hold the copyright. 
Jurnal Inspirasi Pendidikan, VOL.9, NO.1, Edisi Januari 2019

Penerapan Model Scramble untuk Meningkatkan Motivasi Belajar

pada Mata Pelajaran Pendidikan Pancasila dan Kewarganegaraan Prodensia Tuku $^{\text {a, }{ }^{*} \text {, Bhakti Prima Findiga Hermuttaqien }}{ }^{\text {b, } 2}$, Iskandar Ladamay ${ }^{\text {c, } 3}$

Hal: 45-51

\section{Pendahuluan}

Pendidikan menurut UU No.20 Tahun 2013 tentang SISDIKNAS pasal 1 menyatakan bahwa Pendidikan merupakan usaha sadar dan terencana yang mempunyai tujuan mempersiapkan peranan peserta didik dalam kehidupan sehari-hari dimasa yang akan datang melalui bimbingan, pelatihan dan pengajaran. Fungsi pendidikan nasional ialah mengembangkan dan membentuk karakter dalam rangka mencerdaskan kehidupan bangsa dan negara(Hasbullah, 2011). Hal ini sejalan dengan pendapat (Mardenis, 2017) bahwa tujuan pendidikan nasional mengembangkan potensi-potensi yang dimiliki oleh peserta didik agar menjadi manusia yang berakhlak mulia dan berintelektual tinggi, kreatif, inovatif, mandiri, dan mampu menjadi warga negara yang demokratis, jujur, serta bertanggung jawab. Adapun aspek-aspek yang harus dicakup dalam dunia pendidikan meliputi aspek bimbingan, aspek pengetahuan, dan aspek pengajaran. Ketiga aspek tersebut harus betul-betul dipahami oleh guru sebagai (Sanjaya, 2008)

Pendidikan Kewarganegaraan ( $\mathrm{PKn}$ ) merupakan salah satu bentuk pendidikan yang secara intensif membentuk karakter, nilai, moral, dan sikap perilaku peserta didik dalam rangka membantu memanusiakan manusia (Komalasari, 2014). PKn telah direorganisasi menjadi kurikulum pendidikan dasar disetiap jenjang Pendidikan baik dari tingkat SD, SMP, SMA sampai pada tingkat perguruan tinggi (Eurydice, 2018).(Fernanda Nogueira, 2016) berpendapat bahwa Pendidikan Kewarganegaraan telah didefinisikan sebagai suatu hak istimewa bagi seluruh warga Negara untuk pengembangan dan pelaksanaan kewarganegaraan. Pendidikan Kewarganegaraan diharapkan untuk dapat memberikan sudut pandang transdisipliner (sebuah komponen yang berjalan di semua mata pelajaran kurikulum yang menekan pada tiga aspek yaitu pengetahuan sikap dan keterampilan warga Negara), Hal ini sebagaimana tertuang dalam undang-undang lama yaitu undang-undang nomor 2 tahun 1989 tentang sistem pendidikan nasional. Selanjutnya tetap dipertahankan sebagai pendidikan wajib menurut ketentuan baru undang-undang sistem pendidikan nasional yaitu undang-undang nomor 20 tahun 2003 tentang sistem pendidikan nasional.

Tujuan PKn pada dasarnya adalah menjadikan warga negaranya, menjadi warga negara yang baik, cerdas serta berupaya untuk mempromosikan pengayaan global siswa agar berpartisipasi aktif dalam kehidupan bermasyarakat sebagai warga negara yang mampu bertanggung jawab terhadap diri sendiri masyarakat, bangsa dan negara. Menurut (Tesfaye Semela, 2013) pendidikan kewarganegaraan juga memiliki tujuan untuk menanamkan nilai-nilai demokrasi, tanggung jawab, kerja sama yang baik sehingga siswa sebagai warga negara akan berperan aktif dalam masyarakat. Berdasarkan pendapat diatas dapat disimpulkan bahwa upaya mewarganegarakan individu, kelompok atau orang-orang yang hidup dalam suatu wilayah negara merupakan tugas pokok negara dalam artian pemerintah, dan guru-guru di sekolah, terutama guru mata pelajaran PKn yang dituntut untuk dapat membawa perubahan pada sikap dan perilaku peserta didik, agar mampu menjadi warga negara yang baik. Tuntutan bagi guru PKn tersebut bukanlah hal yang baru didengar namun itu adalah tuntutan lama yang harus diperhatikan oleh guru PKn karena sejak awal lahirnya mata pelajaran PKn memang didesain sebagai upaya untuk mempersiapkan warga negaranya menjadi warga negara yang baik yang mampu berpartisipasi didalam kehidupan bermasyarakat (Zamroni, n.d, 2003c)

PKn mempunyai tiga kompetensi dasar yang harus dimilki oleh warga negara Indonesia yaitu: civic knowledge, civic skill, civic disposition (Ubaedillah, 2015) Civic knowledge yaitu pengetahuan yang yang harus diketahui atau dimiliki oleh warga negara tentang negaranya. Civic skill yaitu keterampilan yang harus dimiliki oleh warga negara, keterampilan itu meliputi: keterampilan dalam memecahkan suatu permasalahan sosial yang ada dalam negara, keterampilan intelektual, keterampilan sikap dan keterampilan berpartisipasi. Civic disposition yaitu berkaitan dengan karakter privat dan publik dari warga negara yang perlu dipelihara dan ditingkatkan dalam demokrasi.

Berdasarkan sistem kurikulum 2013 menekankan pada keaktifan siswa dalam proses pembelajaran karena siswa tidak hanya mendengar, mencatat, merangkum apa yang disampaikan oleh guru akan tetapi siswa diharuskan untuk mencari dan memecahkan permasalahan yang ditugaskan oleh guru dan guru sebagai monitoring yang mengarahkan dan membimbing siswa selama proses pembelajaran (Abduhzen, 2013). Reformasi pendidikan diabad 21 telah menekankan bahwa semua guru dalam proses pembelajaran harus berpusat pada siswa dalam pendekatan pembelajaran (Anne jordan, 2016). Pendapat tersebut memiliki kolerasi dengan mata pelajaran PKn yang dirancang 
Jurnal Inspirasi Pendidikan, VOL.9, NO.1, Edisi Januari 2019

Penerapan Model Scramble untuk Meningkatkan Motivasi Belajar pada Mata Pelajaran Pendidikan Pancasila dan Kewarganegaraan Prodensia Tuku $^{\text {a, }{ }^{*} \text {, Bhakti Prima Findiga Hermuttaqien }}{ }^{\text {b, } 2}$, Iskandar Ladamay ${ }^{\text {c, } 3}$

Hal: 45-51

berbasis aktivitas yang berkaitan dengan kewarganegaraan yang diharapkan bahwa setelah mempelajari PKn dapat mendorong siswa untuk menjadi warga negara yang baik (good citizen) melalui kepedualiannya terhadap permasalahan-permasalahan yang ada disekitarnya, kepedulian siswa dapat ditunjukan dengan berpartisipasi aktif dalam kegiatan pengembangan diri di dalam kelas maupun di luar lingkungan kelas(Lukman Dkk, 2017)

Merujuk dari penjelasan paragraf diatas dan pendapat (Sumantri, 2016) bahwa guru PKn mempunyai peran yang penting dalam usaha untuk menjadikan warga negara Indonesia menjadi warga negara yang baik melalui pembelajaran PKn yang dimana dalam mata pelajaran PKn berfungsi sebagai pengembangan dan pelestarian nilai-nilai luhur serta moral, dan karakter yang berakar pada budaya, kebiasaan bangsa Indonesia yang diwujudkan dalam pemahaman, perilaku dan kesadaran siswa dalam kehidupan sehari-hari untuk menjadi warga negara yang baik. Guru harus memiliki keseimbangan antara pembelajaran di kelas dan pengalaman belajar di luar kelas sehingga bisa konsisten dengan peran dan tanggung jawab di kelas (Richard A. Villa, 2017) Berdasarkan penjelasan tersebut maka seorang guru PKn harus mampu mengaitkan materi yang disampaikan dengan pengalaman hidup siswa dalam hidup bermasyarakat, karena pembelajaran PKn tidak hanya mengkaji pada tataran kognitif yang harus dimilki siswa akan tetapi menyentuh pada tataran keterampilan dan sikap yang harus dimilki siswa, dengan demikian diharapkan agar siswa mampu mengembangkan aspek kognitif dan tidak mengesampingkan aspek psikomotorik dan aspek afektif, sesuai dengan sistem kurikulum 2013 yang berlaku saat ini.

Berdasarkan hasil wawancara awal, sebagian siswa berpendapat bahwa pembelajaran Pendidikan kewarganegaraan(PKn) merupakan pembelajaran yang sangat membosankan dan kurang menarik bagi siswa, selain itu sebagian siswa juga berpendapat bahwa mata pelajaran PKn adalah mata pelajaran hafalan yang sangat melelahkan untuk dipelajari dan tidak memberikan dampak yang penting untuk masa depan mereka dibandingkan dengan mata pelajaran lainnya seperti seperti Matematika dan ilmu pendidikan alam (MIPA), Bahasa Inggris, Bahasa Indonesia,Ilmu pengetahuan sosial (IPS ) dan lain sebagainya hal tersebut dikareanakan selama kegiatan pembelajaran guru sellalu menggunakan model yang bersifat konvensioanl dimana kurang melibatkan siswa dalam prose pembelajaran di kelas sehingga pemikiran-pemikiran tentang kurang pentingnya pendidikan ewarganegaraan timbul dalam rasio atau pikiran siswa pernyatan terbut di ungkapkan oleh (Jusmiati, 2018)

Guru harus memberikan kebebasan bagi siswa untuk berkreasi dan mengekspresikan kemampuannya agar siswa dapat berkembang secara optimal (Lukman Dkk, 2017). Berdasarkan pendapat diatas dapat disimpulkan bahwa untuk tercapainya kompetensi tersebut seorang guru harus mampu kreatif dan inovatif dalam proses pembelajaran di kelas sehingga siswa memiliki motivasi dalam mengikuti proses pembelajaran. Motivasi belajar merupakan keseluruhan daya gerak yang timbul dari diri sendiri, maupun dari luar seperti dari teman sebaya dan guru. Salah satu cara yang dapat dilakukan guru untuk meningkatkan motivasi belajar siswa yaitu dengan menggunakan model, teknik, atau pendekatan yang sekreatif mungkin sehingga siswa memiliki semangat dan keinginan belajar khususnya pada mata pelajran PKn (Winkel, 2004)hal senada juga di ungkapan oleh (Hanafiah, 2012) motivasi belajar merupakan daya dorong atau suatu keinginan yang kuat yang timbul dari dalam diri peserta didik untuk belajar secara aktif, kreatif, efektif, inovatif, interaktif dan menyenangkan dalam perubahan perilaku yang terdiri dari berbagai aspek, baik itu aspek kognitif, afektif dan psikomotorik.

Berdasarkan hasil penelitian terdahulu yang dilakukan oleh (Jusmiati, 2018) yang membahas tentang peningkatan hasil belajar siswa dengan permasalahan menurunya hasil belajar siswa pada mata pelajaran PKn . dan (Nasrul, 2018) yang mengakaji tentang upaya peningkatan hasil belajar siswa dengan permasalahan menurunnya hasil belajar siswa serta (Roy Bawe, 2018) yang mengkaji tentang kerjsama siswa pada mata pelajaran PKn dengan fokus permasalahan yaitu kurangnya kerjasama siswa dalam proses pembelajaran di kelas. Sehingga dari 3 penelitian terdahulu tersebut dengan mengkaji permasalahan yang sama, tetapi pada penelitian ini peneliti lebh memfokuskan kepada pengaruh kurangnya motivasi belajar siswa pada mata pelajaran PKn hal tersebut di lakukan peneliti dengan tujuan untuk melengkapi hasil penelitian terdahulu. 
Jurnal Inspirasi Pendidikan, VOL.9, NO.1, Edisi Januari 2019

Penerapan Model Scramble untuk Meningkatkan Motivasi Belajar pada Mata Pelajaran Pendidikan Pancasila dan Kewarganegaraan
Prodensia Tuku $^{\text {a, } 1^{*}}$, Bhakti Prima Findiga Hermuttaqien

Hal: 45-51

Berdasarkan permasalahan diatas maka peneliti mengusulkan model yang dapat diterapkan dalam proses pembelajaran PKn yakni "Model Scramble" menurut (Suyanto, 2018) bahwa Model Scramble dapat digunakan untuk meningkatkan motivasi belajar siswa karena Model Scramble merupakan salah satu model yang dapat merangsang siswa untuk berpikir kritis, kreatif, aktif, efektif, interaktif dan menyenangkan bagi siswa. Model scramble juga model yang menekankan kerja siswa agar konsep-konsep pembelajaran atau tujuan pembelajaran mudah dimengerti dan bertahan lama dalam struktur kognitif siswa. Model scramble dapat membangkitkan semangat dan motivasi belajar siswa pada mata pelajaran PKn, sehingga permasalahan-permasalahan yang terjadi selama proses pembelajaran dapat teratasi F. Diza 2016 (Komalasari, 2014)

Ketiga kompetensi tersebut dapat tercapai apabila seorang guru mampu inovatif dan kreatif dalam proses pembelajaran dengan menggunakan model-model pembelajaran yang dapat digunakan untuk meningkatkan ketiga kompetensi yang harus dimilki siswa tersebut. Salah satu model yang dapat digunakan ialah model pembelajaran Scramble karena model pembelajaran tersebut salah satu model pembelajaran yang mudah untuk diterapkan (Suyanto, 2018). Menurut (Asih, 2018) model scramble merupakan model pembelajaran yang bersifat aktif yang selalu menuntut siswa untuk selalu bekerjasama secara kelompok dalam menyelesaikan kartu soal yang diberikan oleh guru untuk mendapatkan poin yang bagus dalam kelompoknya. Setiap siswa dilatih bekerjasama dengan harapan dapat meningkatkan nilai kebersamaan dalam belajar

Kesesuaian antara model pembelajaran Scramble dengan mata pelajaran PKn yaitu, bahwa pada mata pelajaran PKn mempunyai tiga kompetensi yang harus dimilki oleh siswa, yakni: civic knowledge, civic skill, civic disposition. Menurut(Ubaedillah, 2015) yaitu: Civic knowledge yaitu pengetahuan yang yang harus diketahui atau dimiliki oleh warga negara tentang negaranya. Civic skill yaitu keterampilan yang harus dimiliki oleh warga negara, keterampilan itu meliputi: keterampilan dalam memecahkan suatu permasalahan sosial yang ada dalam negara, keterampilan intelektual, keterampilan sikap dan keterampilan berpartisipasi. Civic disposition yaitu berkaitan dengan karakter privat dan publik dari warga negara yang perlu dipelihara dan ditingkatkan dalam demokrasi sedangkan pada model sramble siswa dilatih untuk mampu secara pengetahuan, sikap dan keterampilan. Jadi dari penjelasan diatas maka ada kesesuaian antara model scramble dan tujuan pembelajaran PKn yang dimana tidak hanya menekan pada aspek pengetahuan yang harus dimiliki siswa tetapi juga menekan pada aspek keterampilan dan sikap.

\section{Metode}

Pendekatan penelitian yang digunakan yaitu pendekatan kuantitatif dengan jenis penelitian quasi eksperimen. Kuasi eksperimen merupakan metode penelitian yang memiliki perlakukan, pengukuran dampak, kelompok eksperimen namun tidak menggunakan penugasan secara acak untuk menciptakan perbandingan dalam rangka menyimpulkan perubahan yang disebabkan oleh perlakuan sampel yang digunakan yaitu sampel kelas eksperimen dan sampel kelas kontrol dengan jumlah responden di setiap kelas yaitu 32 siswa dari kedua sampel tersebut dengan total sampel dalam penelitia yaitu 64 orang. teknik pengumpulan data yang digunakan yaitu dokumentasi, wawancara dan kuesioner atau angket. analisis data yang digunakan oleh peneliti yaitu dengan menggunakan rumus kriteria peningkatan motivasi belajar siswa, dan uji independent sample t-test, untuk mengukur peningkatan motivasi belajar siswa pada mata pelajaran PKn yang diperoleh dari kedua sampel tersebut setelah mendapatkan perlakuan dengan menggunakan model scramble dana model konvensional.

\section{Hasil dan pembahasan}

1. Uji hasil menggunakan rumus kriteria peningkatan motivasi belajar

Keberhasilan dalam proses pembelajaran, dipengaruihi oleh, niat keinginan dan motivasi siswa dalam belajar, untuk mengukur motivasi belajar siswa setelah mendapata perlakuan dalam proses belajar dengan menggunakan model scramble peneliti menguji dengan dua cara yaitu rumus kriteria peningkatan motivasi belajar dan uji independent sample t-test. Kedua uji tersebut di ambil dari hasil post test siswa setelah mendaptkan perlakukan dan berdasarkan hasil analisis post-test kelas eksperimen dan kelas kontrol menunjukan prosentasi peningkatan motivasi 
Jurnal Inspirasi Pendidikan, VOL.9, NO.1, Edisi Januari 2019

Penerapan Model Scramble untuk Meningkatkan Motivasi Belajar pada Mata Pelajaran Pendidikan Pancasila dan Kewarganegaraan
Prodensia Tuku $^{\text {a, } 1^{*}}$, Bhakti Prima Findiga Hermuttaqien

Hal: 45-51

belajar siswa pada mata pelajaran PKn memiliki perbedaan yang sangat signifikan antara kedua kelas tersebut. Pada kelas eksperiment dengan jumlah responden 32 orang mendapatkan prosentasi $93,5 \%$ dari hasil prosentasi tersebut menyatakan sangat baik berdasarkan tabel interval kriteria peningkatan motivasi belajar siswa dengan prosentasi sangat baik interval $84 \%$ 100\%. sedangkan prosentasi yang diperoleh pada kelas kontrol dengan jumlah responden 32 orang memperoleh prosentasi $65,3 \%$. Dari hasil prosentasi tersebut menyatakan cukup baik berdasarkan tabel kriteria peningkatan motivasi belajar siswa dengan prosentasi kurang baik interval $>52 \%-68 \%$. Hal ini menunjukan bahwa penerapan model scramble mempunyai pengaruh yang sangat signifikan untuk meningkatkan motivasi belajar siswa pada mata pelajaran PKn hasil tersebut di uji dengan rumus sebagai berikut:

Keterangan:

$$
\%=\frac{n}{N} N 100 \%
$$

$\mathrm{n} \quad=$ nilai yang diperoleh

$\mathrm{N} \quad=$ jumlah Total Responden kelas eksperimen

$\%=$ presentasi (Ali, 2000)

Pada kelas eksperimen hasil yang di peroleh dengan menggunakan rumus keriteria peningkatan motivasi belajar adalah:

$$
\begin{aligned}
& \%=\frac{2992}{32} \times 100 \% \\
& =93,5 \%
\end{aligned}
$$

Pada kelas kontrol hasil yang di peroleh dengan menggunakan rumus keriteria peningkatan motivasi belajar adalah:

$$
\begin{aligned}
\% & =\frac{2090}{32} \times 100 \% \\
& =65,3 \%
\end{aligned}
$$

Tabel kriteria peningkatan motivasi belajar (Ali, 1999)

\begin{tabular}{|l|l|}
\hline Interval & Kreteria \\
\hline $84 \%-100 \%$ & Sangat baik \\
\hline$>68 \%-84 \%$ & Baik \\
\hline$>52 \%-68 \%$ & Cukup baik \\
\hline$>36 \%-52 \%$ & Kurang baik \\
\hline$>20 \%-36 \%$ & Tidak baik \\
\hline
\end{tabular}

Dari hasil uji kriteria peningkatan motivasi belajar yang diperoleh dari kedua sampel pada penelitian ini yaitu pada sampel kelas eksperimen memperoleh prosentase 93,5\% dalam tabel kriteria peningkatan motivasi belajar dengan rentan intervalnya 84\%-100\% dinyatakan sangat baik, sedangkan pada sampel kelas kontrol memperoleh prosentase 65,3\% dalam tebel kriteria peningkatan motivasi belajara dengan rentan interval 52\%-68\% dinyatakan cukup baik, jadi dapat disimpulkan bahwa penerapan model scramble dapat meningkatkna motivasi belajar siswa pada mata pelajaran PKn yang di lihat dari hasil prosesntase dari kedua sampel tersebut.

2. Uji hasil menggunakan uji independet sample t-test pada spss varsi 22,0 windows

Uji independent sample t-test yang digunakan untuk mengukur perbedaan kedua smpel yang tidak berpasangan. Sampel tidak berpasangan yang di maksudkan adalah sampel kelas eksperimen dan sampel kelas kontrol dengan jumlah responden yang sama yaitu 32 siswa dari masing-masing sampel. Hal ini bertujuan agar data yang diperoleh dapat memberikan hasil yang valid dan reliabel. maka peneliti melakukan uji independent sample t-test yang diambil dari hasil post-test setelah peneliti melakukan perlakuan model eksperimen dan model konvensional. Berikut ini hasil uji independen sample t-test pada SPSS versi 22,0 for windows: 
Jurnal Inspirasi Pendidikan, VOL.9, NO.1, Edisi Januari 2019

Penerapan Model Scramble untuk Meningkatkan Motivasi Belajar pada Mata Pelajaran Pendidikan Pancasila dan Kewarganegaraan
Prodensia Tuku $^{\text {a, } 1^{*}}$, Bhakti Prima Findiga Hermuttaqien

Hal: 45-51

Tabel uji independent sample t-test

\begin{tabular}{|c|c|c|c|}
\hline & \multicolumn{3}{|c|}{ T- Test For Equality Of Means } \\
\hline & Df & Sig. (2-Tailed) & Mean Difference \\
\hline Hasil equal variannces ulan assumed & 62 & .000 & 28.188 \\
Gan equal variances not PKn assumed & 41.93 & .000 & 28.188 \\
\hline
\end{tabular}

Adapun dasar pengambilan keputusan uji independent samples t-test adalah jika nilai sig.(2tailed) $<0.05$ maka terdapat perbedaan yang signifikan. Dari hasil uji independet sample t-test yang diperoleh di atas yaitu sig.(2-tailed) adalah 0,000 maka dapat disimpulkan bahwa ada perbedaan yang sangat signifikan antara kedua sampel tersebut yaitu sampel kelas eksperiment dan sample kelas kontrol.

Dari rumusan masalah yang dikaji peneliti untuk mencari apakah ada pengaruh yang signifikan penerapan model scramble untuk meningkatkan motivasi belajar siswa pada mata pelajaran PKn. dari hasil penelitian yang dikaji diatas menunjukan ada pengaruh signifikan penerapan model scramble untuk meningkatkan motivasi belajar siswa pada mata pelajaran PKn yang diuji dengan menggunakan rumus kriteria peningkatan motivasi belajar dan uji independen sampel $\mathrm{t}$-test. Dari hasil rumus peningkatan motivasi belajar memperoleh hasil prosentasi 93,5\% dari hasil prosentasi tersebut menyatakan sangat baik dengan jumlah responden 32 orang pada kelas eskperiment sedangkan pada kelas kontrol memperoleh hasil prosentasi 65,3\%. Dari hasil prosentasi tersebut menyatakan cukup baik, sehingga dari kedua sampel tersebut yang memperoleh hasil prosentasi paling tinggi yaitu kelas eksperimen yang belajar menggunakan model Scramble, dan berdasarkan hasil uji independen sample t-test dari kedua sampel tersebut mendapatkan hasil yaitu sig.(2-tailed) adalah 0,000 , maka terdpat perbedaan dari kedua sampel tersebut.

\section{Simpulan}

Peningkatan motivasi belajar tersebut dapat dilihat dari hasil prosentasi yang diukur dengan menggunakan rumus kriteria pengingkatan motivasi belajar siswa. Pada kelas eksperimen jumlah responden 32 dengan memeperoleh prosentasi sebesar 93,5\% dan pada kelas kontrol dengan jumlah responden 32 orang memperoleh prosentasi $65,3 \%$, rentang perbedaan dari kedua sampel tersebut adalah 34,45\%. hasil uji Idependent sampel t-test yang diperoleh yaitu sig.(2-tailed) pada kelas kontrol dan kelas eksperimen adalah adalah 0,000 maka dapat ditarik kesimpulannya adalah ada perbedaan yang sangat signifikan antara kelas eksperiment dan sample kelas kontrol yang diuji oleh peneliti pada bagian analisis data.

\section{Referensi}

Abduhzen. (2013). Kurikulum 2013, Profesionalisme Guru Antara Harapan Kenyataan”. Suara Guru (Edisi Mei-Juni 2013)

Anne jordan. (2016). Mempersiapkan guru untuk kelas inklusif. (https://doi.org/10.1016/j.tate.2009.02.010 di akses pada tanggal 20 oktober 2018)

Asih. (2018). Peningkatan Kualitas Pembelajaran PKn Melalui Model Pembelajaran Scramble Berbasis Power Point Pada Siswa Kelas Va. Sdn Bendan Ngisor Kota Semarang “ Skripsi Pada Universitas Muria Kudus Fakultas Keguruan Dan Ilmu Pendidikan Programn Studi PGSD : Tidak Diterbitkan. ( Diakases Pada Tanggal 7 Juli 2018)

Eurydice, T. W. S. (2018). Pendidikan kewarganegaraan - persepsi siswa Portugis (https://doi.org/10.1016/j.sbspro.2011.03.367. di akses pada tanggal 11 April 2018)

Fernanda Nogueira. (2016). Pendidikan kewarganegaraan - persepsi siswa Portugis (https://doi.org/10.1016/j.sbspro.2011.03.367. di akses pada tanggal 11 April 2018)

Hanafiah. (2012). Konsep Strategi Pembelajaran. Bandung: Refika Aditama

Hasbullah. (2015). Sistem Pendidikan Nasional. Jakarta: Rajawali Pers

jusmiati. (2018). Jusmiati. 2016. Penerapan Metode Dikusi Kelompok Pada Mata Pelajaran PKn

Untuk Meningkatkan Hasil Belajar Siswa Kelas IV SDN 2

Bilo(http://jurnal.untad.acid/jurnal/index.php. di akses pada tanggal 6 juli 2018).

komalasari. (2014). Pembelajaran Kontekstual. Bandung : Refika Aditama.

Lukman. (2017). Pendidikan Pancasila Dan Kewaranegaraan. Jakarta: Gramedia 
Jurnal Inspirasi Pendidikan, VOL.9, NO.1, Edisi Januari 2019

Penerapan Model Scramble untuk Meningkatkan Motivasi Belajar pada Mata Pelajaran Pendidikan Pancasila dan Kewarganegaraan
Prodensia Tuku $^{\text {a, }}{ }^{*}$, Bhakti Prima Findiga Hermuttaqien

Hal: 45-51

Mardenis. (2017). Mardenis. 2017. Pendidikan Kewargasnegaraan Dalam Rangka Pengembangan Kepribadian . Jakarta: Rajagrafindo Persada, 2017.

Nasrul. (2018). Penerapan Model Pembelajaran Round Table Dalam Upaya Meningkatkan Hasil Belajar siswa pada mata pelajaran PKn kelas VI SD Negeri 004 Domo Kecamatan Kampar kiri (http:/www.google.co.id/nasrul+2016+penerapan+model+round+table+pada+mata+pelajaran PKn. di akses pada tanggal 6 juli 2018)

Richard A. Villa. (2017). Pengajaran kolaboratif untuk pendidik guru - Apa yang dikatakan oleh penelitian. (https://doi.org/10.1016/j.tate.2009.02.009 di akses pada tanggal 20 oktober 2018)

Roy Bawe. (2018). Roy Bawe. 2015. Penerapan Model Pembelajaran Kooperatif Tipe Jigsaw Untuk Meningkatkan Kerjasama Siswa Pada Mata Pelajaran PKn Kelas IV Di SDN Kledokan Depok. (http://journal.student.uny.ac.id di akses pada tanggal 6 juli 2018), 2018.

Sanjaya, W. (2008). Perencanaan dan desain sistem pembelajaran. Jakarta: Kencana Prenada Media Group., 2008.

Sumantri. (2016). Strategi Pembelajaran Teori Dan Praktik Ditingkat Dasar. Jakarta: Rajagrafindo Persada

Suyanto. (2018). Strategi Meningkatkan Kualifikasi Guru Dan Kualitas Guru Di Era Global: Erlangga.

Tesfaye Semela. (2013). Jurnal 19. Andi P. Jurnal Internasional Pengembangan Pendidikan, 33, 156164.

Ubaedillah. (2015). Pendidikan Kewarganegaraan. Bandung : Refika Aditama.

winkel. (2004). Psikologi Pendidikan Dan Evaluasi Belajar. Jakarta: PT Gramedia Pustaka Utama.

zamroni. (n.d.). Zamroni. 2003c. Pendidikan Kewarganegraan: tradisi dalam memelihara kehidupan majemuk, Warta PTM Edisi7 Th.XV,10-11 (Warta PTM). 